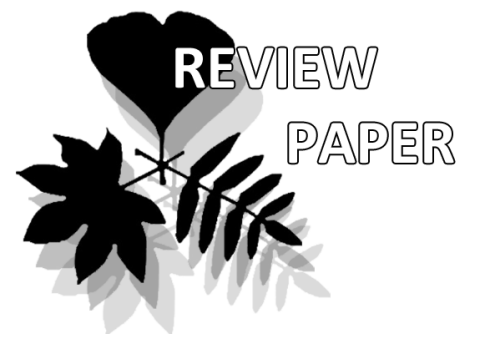

Natalia E. Zavialova

e-mail: zavial@mail.ru

A.A. Borissiak Paleontological Institute, Russian Academy of Sciences, Moscow 117647 Russia

Manuscript received: 11.08 .2015

Review completed: 05.10.2015

Accepted for publication: 12.10 .2015

Published online: 20.10.2015

\section{Evolutionary Transformations of Sporoderm Ultrastructure in Certain Monophyletic Lineages of Higher Plants}

\author{
Natalia E. Zavialova
}

\begin{abstract}
A B S T R A C T
Data of transmission electron microscopy can be successfully used to reveal evolutionary transformations, which occurred in pollen or spores during the existence of monophyletic lineages of higher plants. On the basis of such data, one can discover gradual transitions in groups, which include new forms, that at the first glance seem to be totally dissimilar to the predecessors. One can trace sequences of morphological transitions within lineages from the earliest to latest members of a given group and connect the first and last members, which do not share any common features. Hidden transformations are traceable in groups, which seemed unchanged during the entire period of their existence. Parallelisms can be revealed between unrelated groups of higher plants not only in final forms, but also in succession of transformations. The successful application of this approach has been exemplified in lyginopteridaleans, peltasperms, equisetaleans, and the Cheirolepidiaceae. Particularly promising seem groups that have a long geological history and survive until now.
\end{abstract}

Ke ywords : sporoderm ultrastructure, evolutionary transformations, peltasperms, lyginopteridaleans, horsetails, Cheirolepidiaceae

\section{P E 3 Ю M E}

Завьялова Н.Е. Эволюционные преобразования в ультраструктуре спородермы в некоторых монофилетических группах высших растений. Аанные трансмиссионной электронной микроскопии могут с успехом применяться Аля выяв еения эволюционных преобразований в ультраструктуре пыльцевых зерен или спор, происходивших в монофилетических Аиниях высших растений. На основе таких данных можно находить постепенные переходы в тех случаях, когда новые и совершенно не похожие на преАшественников формы возникали в геологической метописи на первый взгляд внезапно. Можно прослеживать последовательные морфологические преобразования в ряду от самых ранних к самым поздним представитеАям определенной группы, что удается даже если межАу первыми и послеАними членами цепи вообще не наблюдается сходных признаков. Скрытые преобразования удается проследить в группах, казалось бы остававшихся практически не измененными в течение всего периода их существования. Могут быть выявлены параллелизмы межАу неродственными группами высших растений, касающиеся не только отдельных стадий, но и последовательностей преобразований, которые к этим стадиям привели. В качестве примеров рассмотрены мигиноптерисовые и пельтаспермовые семенные папоротники, хвощи, хейролепидиевые. Особенно перспективными преАстав яяются группы, имеющие АлитеАьную геологическую историю и АОжившие Ао настоящего времени.

К $\boldsymbol{\Lambda}$ ю ч е в ы е с $\mathbf{\Lambda}$ о в а : ультраструктура спородермы, эволюционные преобразования, пельтаспермовые, Аигиноптеридиевые, хвощи, хейролепидиевые
In my perception, the morphology and ultrastructure of fossil pollen and spores are such an interesting subject that even little discoveries of novelties are worth of spent efforts. It is even truer nowadays, when few scientists continue dealing with the ultrastructure of fossil exines. Quite often, when I am curious to learn about the inner structure of a given type of fossil spores or pollen, a search in the published literature does not help, and the only way to get this information is to study it with TEM myself. The current knowledge on the sporoderm is very limited and the situation will hardly change to the best within my lifetime. However, already obtained data invite to generalize over them, in spite of the fact that they are always incomplete and often incomparable. There are "palynological puzzles" that have attracted the attention of pollen morphologists for a long time (Chaloner 2013). Some of such puzzles seem less unsolvable than others. For example, this is probably the case of pollen and spores of some monophyletic groups of higher plants and transformations that took place in their morphology and sporoderm ultrastructure in course of the evolution. Using such groups as preferable objects of ultrastructural studies of sporoderms could be very prospecting in the following aspects: 
- It often seems that new forms appeared in some long-living groups of higher plants suddenly and that they were completely dissimilar to earlier forms of the group. Ultrastructural studies can show that morphological transitions did exist and gradational evolution did take place even in such cases.

- Moreover, we can confidently trace a succession of morphological transformations from the earliest to latest members of a given group. As a result, one can reveal a connection between the first and the last links of the lineage, even in the case when the latest links have lost any similarity to the earliest links.

- We can prove that morphological evolution did take place in groups which appeared unchanged during the entire period of their existence.

- We can discover parallelisms between unrelated groups not only in final evolutionary stages, but also in chains of morphological transformations, which led to them.

Below these aspects are considered in several examples, such as peltasperms, lyginopteridaleans, equisetaleans, and the Cheirolepidiaceae.

\section{A transition between such dissimilar types as saccate and non-saccate pollen: the Peltaspermaceae}

The Permian/Triassic family of seed ferns Peltaspermaceae is an example, where a morphological transition was revealed between apparently dissimilar earlier and later forms. The family is very diverse in pollen morphology by comparison to other gymnosperm families. Peltasperm pollen organs are known to contain the following pollen types: bisaccate striate Protohaploxypinus, bisaccate non-striate Vesicaspora and Falcisporites, non-saccate striate Vittatina, and nonsaccate boat-shaped Cycadopites (Gomankov 1986, Zavialova \& Karasev 2015). Of interest is that nearly all of these pollen types occur not only in peltasperms. The distribution of these types in peltasperms through time is also peculiar. All, but Cycadopites and Falcisporites, are known from peltasperm pollen organs from Permian deposits. Falcisporites associates with peltasperms both in Permian and Early Triassic deposits. Late Triassic members of the family are characterized only by Cycadopites pollen type. By contrast to pollen grains, pollen organs of early and late peltasperms are very similar to each other. The Late Paleozoic fashion on striate and saccate pollen grains, which is known in many unrelated gymnosperm groups, was replaced in the Mesozoic by a fashion on boat-shaped monosulcate non-saccate pollen grains. Peltasperms had their fling to both fashions. In sum, their pollen types were very diverse during the Permian, but were represented by the only one and completely different pollen type at the end of the Triassic.

Until now, the rich diversity of pollen types in the Permian peltasperms has remained unexplainable; and no transitions have been known towards non-saccate monosulcate pollen of late peltasperms. However, it seems that now we can better understand the sudden appearance in the Triassic of a non-saccate pollen type, which replaced the earlier diversity of pollen types, most of which were saccate. Studies of pollen of Permian (Zavialova et al. 2001) and Triassic (Zavialova \& Van Konijnenburg-van Cittert 2011) peltasperms allowed Zavialova \& Van Konijnenburg-van
Cittert (2011) to hypothesize how a transition could have taken place from earlier saccate pollen to later non-saccate pollen. They studied pollen grains from pollen organs of Antevsia zeilleri (Nathorst) Harris 1937 from the Rhaetian of Germany and found that areas of the ectexine that surround the sulcus are thicker than the ectexine of other regions and even slightly resemble sacci by the ultrastructure. Sacci in non-striate saccate pollen grains of Vesicaspora type, which seems the most suitable candidate for this transformation among Permian pollen types of peltasperms (Fig. 1A), could have reduced up to the extensions surrounding the distal sulcus, as it was observed in ultrathin sections of pollen grains of $A$. zeilleri (Fig. 1B-1E). Although a non-saccate pollen type is known in Permian peltasperms (Vittatina), its granulate exine is much more different from that of pollen of Antersia than the exine of Vesicaspora. Among the three saccate types of Permian peltasperms, Vesicaspora was chosen for this reconstruction, because this pollen is not striate; as to Falcisporites, it still waits for a thorough ultrastructural study, which would be better carried out on an in situ material.

A similar morphological transformation was earlier suggested for pollen grains of Ginkgo biloba as a transition to them from saccate pollen of a hypothetical ancestor (Sahashi \& Ueno 1986). Therefore, the morphological transition which was reconstructed for pollen of early and late peltasperms is also an example of a parallelism to an analogous transformation that was reconstructed in a different group of gymnosperms.

\section{Development of a distal aperture in primitive prepollen: the Lyginopteridales}

The seed fern order Lyginopteridales is primitive as far as concerns the general morphology of their prepollen. Prepollen grains found in the majority of their pollen organs are assignable to dispersed genera Cyclogranisporites or Punctatisporites (Balme, 1995). They are subcircular, granulate/punctate, with a trilete proximal scar, and indistinguishable from spores in dispersed state. The ultrastructure of prepollen grains extracted from Crossotheca bughesiana also confirms the primitiveness of the order: the only aperture is the proximal scar, and the ultrastructure of the sporoderm is homogeneous (Taylor \& Taylor 1987; fig. 7). Both features are intrinsic to spores rather than pollen. Orlova et al. (2009) studied the fine morphology of prepollen grains associated with the lyginopteridalean Telangiopsis nonnae Orlova \& Zavialova 2009. By general morphology, these prepollen grains also would be defined as spores if found in dispersed state (Fig. 2B). However, their ectexine is alveolate, and the endexine is lamellate - both features are clearly gymnospermous (Fig. 2C). In addition, although no clearly shaped distal aperture was observed under LM and SEM, ultrathin sections show thinned areas in the exine on both sides of the sporoderm (proximal and distal; Fig. 2A). That means that not only a proximal scar was observed, but also the first step towards the distal aperture (Orlova et al. 2009). The ultrastructure of these prepollen grains is more advanced than their general morphology; it reveals a shift from the spore towards pollen state, that is yet undetectable at the level of general morphology. 

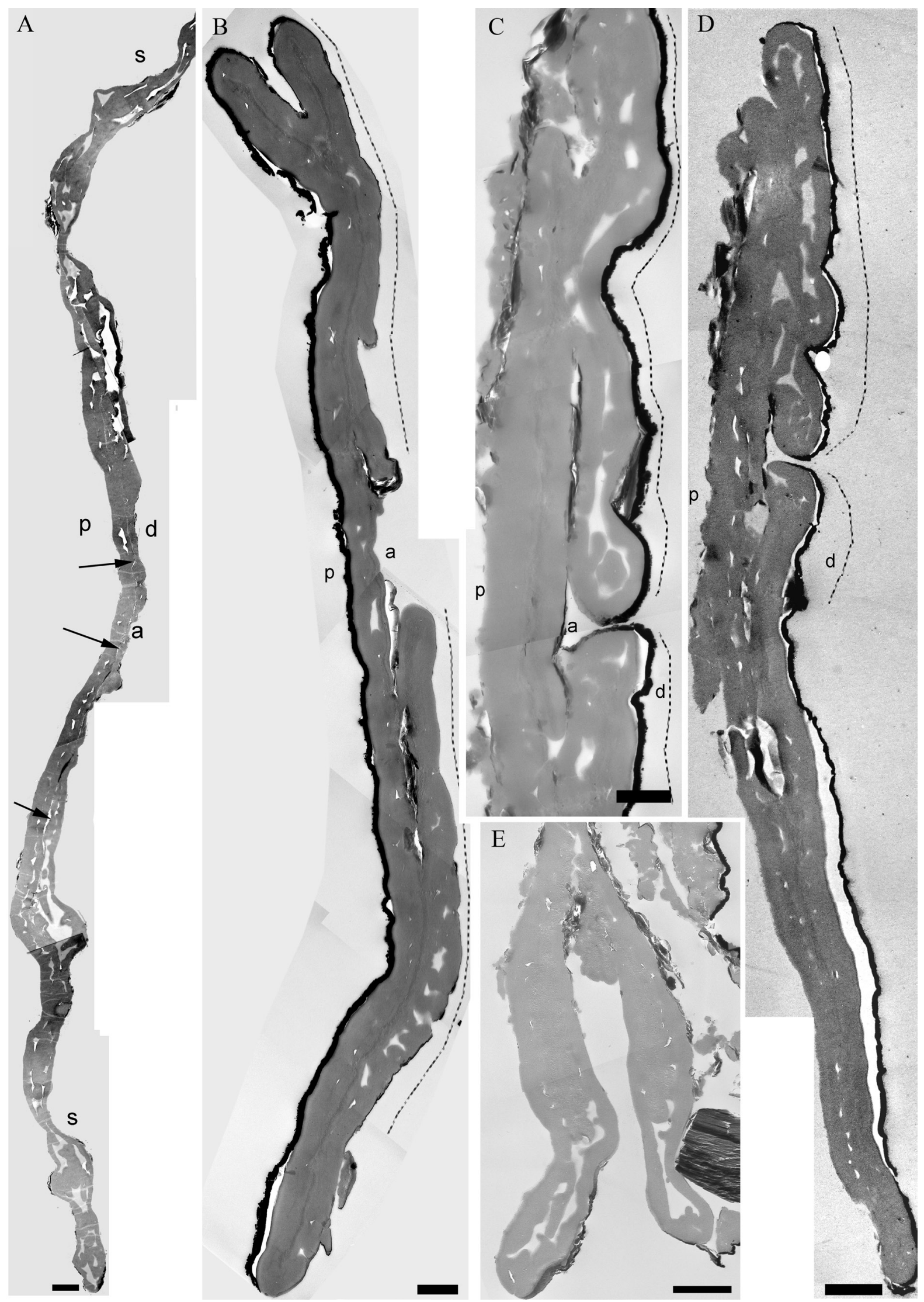

Figure 1 Ultrathin sections of pollen of Vesicaspora sp. and Antevsia zeilleri (Nathorst) Harris 1937 (illustrations are reproduced from Zavialova 1998 and Zavialova \& Van Konijnenburg-van Cittert 2011). A. Pollen of Vesicaspora sp., composite longitudinal section through the body and sacci, proximal face to the left, arrows point to the obliterated gametophyte hollow. B-E. Pollen of A. zeilleri. B. Composite section shows thinned ectexine in the apertural region and extensions of the exine bordering the aperture, proximal face to the left. C. Enlargement of D. D. Composite section of a pollen grain, proximal exine shows regular alveolae, distal-equatorial extensions surround the aperture. E. Section of a pollen grain compressed in lateral position, distal face to the bottom of the figure. Scale bars (A, D, E) $1 \mu \mathrm{m},(\mathrm{B}, \mathrm{C}) 0.67 \mu \mathrm{m}$; (a) aperture, (d) distal face, (p) proximal face, (s) saccus, intermittent line indicates the position of extensions surrounding the aperture 


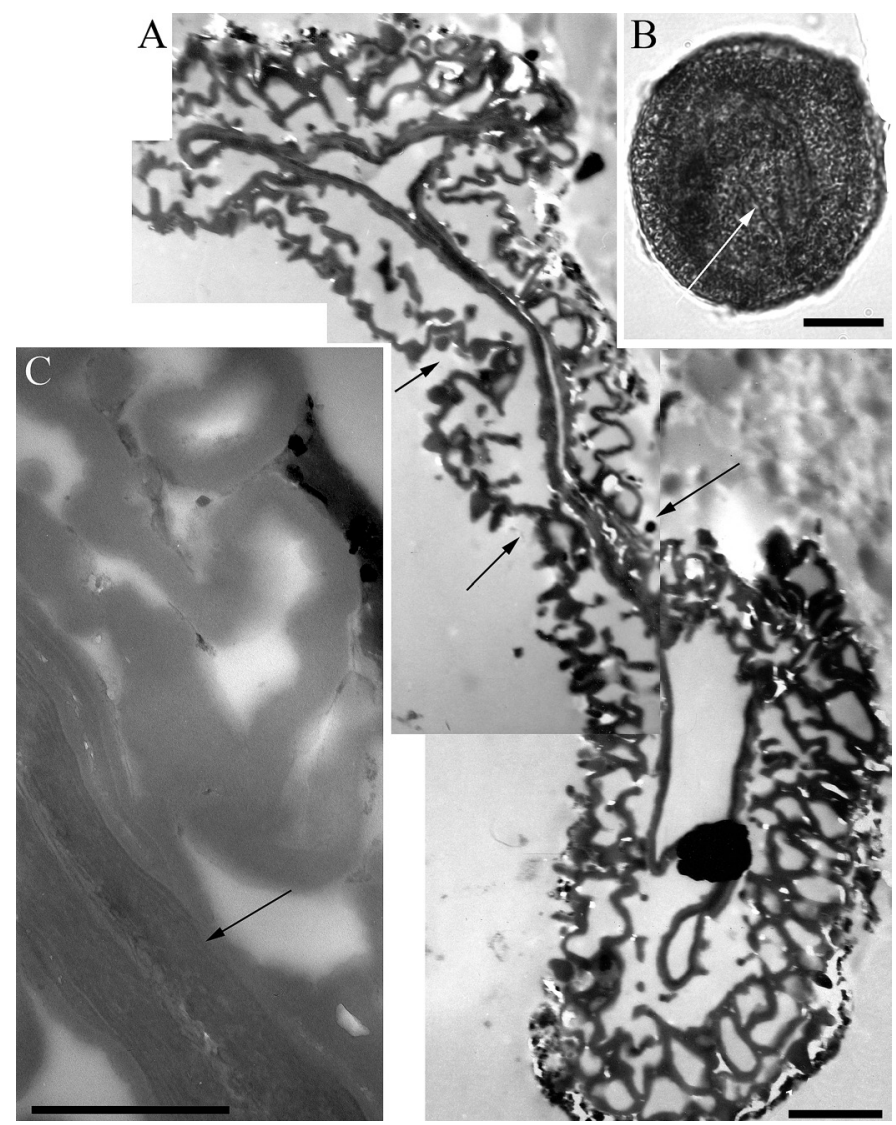

Figure 2 Prepollen grains of Telangiopsis nonnae Orlova \& Zavialova 2009 (illustrations are reproduced from Orlova et al. 2009, pl. VIII). A. Composite image of an ultrathin section, thinned areas are present on both sides of the exine (arrows). B. General view of a prepollen grain, arrow indicates one of three rays of a closed proximal scar, LM. C. Enlargement of the compressed exine, arrow points on the endexine. Scale bar (A) $1.67 \mu \mathrm{m}$, (B) $10 \mu \mathrm{m},(\mathrm{C}) 0.5 \mu \mathrm{m}$

\section{A succession of transformations connects dissimilar morphological types: the Equisetales}

The next example demonstrates a succession of morphological transformations, which connect totally dissimilar first and last members of a group. It was shown that apertural features in spores are usually clearly visible in suitable sections of mature exospores, and are quite different in spores of filicopsids, homosporous and heterosporous lycopsids, and living sphenopsids, and, therefore, they can be successfully used to differentiate between taxa of higher rank of spore-bearing plants (Tryon \& Lugardon 1990). This premise allowed Lugardon \& Brousmuche-Delcambre (1994) and Grauvogel-Stamm \& Lugardon (2009) to reveal evolutionary transformations in the spore morphology and ultrastructure within the Equisetales.

Spores of modern Equisetum have an indistinct small oval aperture. The exospore consists of only two layers (outer and inner exospores), of nearly equal and uniform thickness (Fig. 3e). The outer exospore thins abruptly in the apertural region and forms a pronounced hollow delimiting the exact site of the aperture. The exospore is devoid of any fold in the apertural region, but is inwardly reinforced with a thick, biconvex, lens-shaped mass of sporopollenin, the so-called "sub-apertural obturator", which is attached below the thin apertural wall. It is a unique ultrastructural feature, which is only known in spores of horsetails. The extra-exospore layer (epispore) is present as a thin envelope (Tryon \& Lugardon, 1990). Lugardon studied the sporoderm ultrastructure of in situ Calamospora from Carboniferous sphenophytes (Lugardon \& Brousmuche-Delcambre, 1994). The spores are subcircular, with a trilete proximal scar. In the apertural area, the exospore is thickened and consists of three layers: the lower one is more electrondense, thin, and continuous; the middle one shows a complex stratification with sheets, canals and cavities; and the outer one is much thicker than the inner layer, consists of amorphous sporopollenin and nearly lacks any structural features (Fig. 3a). The apertural fold is strongly protruding. No extra-exospore layers are present. This type of sporoderm ultrastructure differs drastically from that of modern horsetails and, paradoxically, show many similar features to certain ferns, particularly to the Ophioglossales (Lugardon \& Brousmuche-Delcambre, 1994).

It should be pointed out that the latest members of the chain share no common features with the earliest members. To solve this paradox, Lugardon and his coauthors studied spores of horsetails of Triassic and Jurassic ages. They discovered transitional steps in the sporoderm ultrastructure and documented the appearance and further development of features, which later became specific of spores of modern horsetails. The Triassic spores are very close to the Carboniferous spores by the apertural features and sporoderm ultrastructure, but show a tendency of the apertural slit to open at the base and the apertural fold to become less protruding (Fig. 3b). Sporopollenin globules fill a widened area of the apertural fold (Fig. 3c); this filling represents the precursor of the obturator of Equisetum spores. An extraexosporial structure also appeared (extra-exosporial layer is lacking in the Carboniferous spores and is present in modern spores). The Jurassic member shows a further step in the evolutionary modifications (Fig. 3d). These spores seem to be alete and bear short elaters. Although they still shows an apertural fold, the exospore is not thickened in this area anymore and does not show the foliated substructure which characterizes the Carboniferous and Triassic spores. The apertural fold is broadly open and occupied by a mass of sporopollenin that unambiguously corresponds to the obturator. The only primitive vestiges are a slightly developed apertural fold and a few small cavities along its both sides (Grauvogel-Stamm \& Lugardon 2009).

This is an example of how a study of spore morphology and ultrastructure can shed light on the gradational evolution in a plant group, which in the absence of ultrastructural data appeared sudden and interrupted. The above examples about lyginopteridalean prepollen and peltasperm pollen showed only one morphological transformation in each group, whereas the study of horsetail spores discovered several successive transformations. One can connect the first and the last links of chain, even in the case when the latest links have lost any similarity to the earliest links (Fig. 3a, 3e). 


\section{Hidden ultrastructural transformations in seemingly unchanged pollen: the Cheirolepidiaceae}

By means of ultrastructural studies, one can reveal that morphological evolution of pollen or spores did take place even in groups, in which they appeared unchanged during the entire period of the existence of a given group. This will be shown in the Cheirolepidiaceae family, which is a long-living group of gymnosperms. Macrofossil records show that the Cheirolepidaceae appeared as early as in the Late Triassic and became extinct at the end of the Cretaceous (Watson 1988). According to data on dispersed pollen, they appeared in the Late Triassic, existed during the Jurassic and Cretaceous, and, possibly, not for long survived into the Paleogene (Petrosianz \& Bondarenko 1983, Barreda et al. 2012). At the first glance, their pollen morphology is very stable. Watson (1988) noted that Classopollis pollen type is perhaps the only character that all members of this family shared. However, the fact that the general morphology of pollen seems unchanged does not necessarily mean that no changes happened to the sporoderm ultrastructure. On the contrary, the above example of fossil sphenopsids shows that Carboniferous and Triassic spores of the same morphological type differ in the ultrastructure (Grauvogel-Stamm \& Lugardon 2009).

Pollen grains of Classopollis were among the first fossil pollen types ever observed with TEM (Pettitt \& Chaloner 1964); later, they also have been repeatedly studied with help of TEM (see references in Pocock et al. 1990, Kedves 1994, Zavialova et al. 2010ab). Since the already accumulated information on the exine ultrastructure of Classopollis is relatively voluminous, this pollen is a suitable model object for tracing transformations in the inner structure of the exine in course of the evolution of the parent group. Pollen grains of Classopollis are spheroidal, with a small trilete proximal scar, a distal cryptopore, a rimula (= subequatorial circumpolar canal), and an equatorial girdle. The ectexine comprises a double tectum and an infratectum; a foot layer is probably present in some pools of specimens, but lacking in others (Lugardon 1985, Kedves 1994). Several variants of the endexine structure are known, but no directional changes in the endexine are revealed. Even pollen grains from the same sample are shown to have slightly different endexine, supposedly due to slightly different ontogenetic stages, and no endexine, supposedly due to preservation (e.g., Zavialova et al. 2010a). The most famous feature of this pollen type is its ectexine that resembles columellate ectexine of angiosperms and is a common example of angiospermization.

For the aim of the present paper, I focus on the ectexine, since several variants of the infratectum arrangement have been observed in this sublayer and these variants seem to alternate through geological time (Fig. 4). The earliest pollen grains of Classopollis show a rather peculiar granular infratectum. Large granules are mostly arranged in one row, being sandwiched between overlying and underlying layers. This type was revealed in Rhaetian and some Jurassic pollen grains (Fig 4B, 4C): in Classopollis meyerana, C. torosus, and Geopollis zwolinskai from the Rhaetian of England (Zavialova et al. 2010) and Classopollis harrisii from the RhaetianLiassic of France (Médus, 1977).
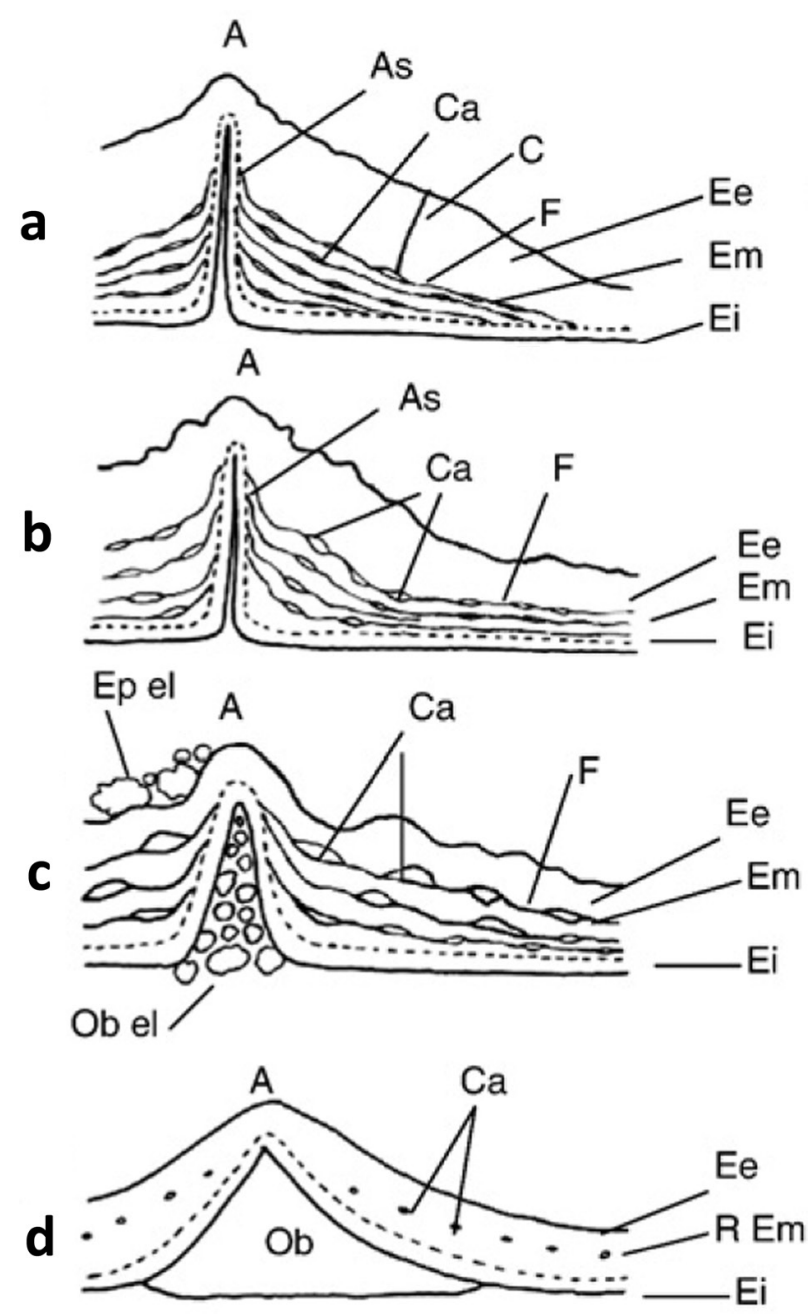

Aa

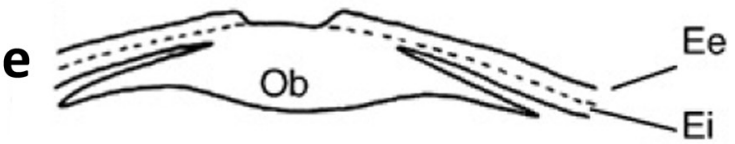

Figure 3 Evolution of the apertural ultrastructure in the Equisetales (figure is redrawn from Grauvogel-Stamm \& Lugardon 2009: fig. 1).

a: Calamites spore of the Calamospora type, Carboniferous; b: Schizoneura - Echinostachys, Triassic; c: Equisetites - Equisetostachys, Triassic; d: Equisetum columnare, Jurassic; e: Equisetum sp., present-day.

$\mathrm{A}=$ apertural fold; $\mathrm{Aa}=$ apertural area; $\mathrm{As}=$ apertural slit; $\mathrm{Ee}=$ external layer of the exospore; $\mathrm{Ei}=$ inner layer of the exospore; $\mathrm{F}=$ sheet; $\mathrm{C}=$ canal; $\mathrm{Ca}=$ cavity; $\mathrm{Ob}=$ sub-apertural obturator; $\mathrm{Ob}$ el $=$ elements of the sub-apertural obturator; Ep el = epispore elements. See Grauvogel-Stamm \& Lugardon $(2009,2010)$ for a more detailed legend

Pollen grains with such an infratectum were later replaced by pollen with an infratectum that was composed of more elongated elements (Fig. 4D); it more and more resembled the columellate infratectum of angiosperm pollen. The structural elements are firmly attached to the overlying layer and can freely hang towards the underlying layer or touch it (Fig. 4E). Pollen grains with such an infratectum were produced during the Jurassic and Early Cretaceous. This transition (from large granules mostly arranged in one row to columella-like elements) is easy to imagine. Some Jurassic Classopollis show alternating columellate-like and 
granular elements (e.g. C. meyerana from the Callovian? of Kazakhstan ${ }^{1}$, Tekleva \& Krassilov 2009; and C. torosus from the Oxfordian of England, Rowley \& Srivastava 1986). However, some other Jurassic and Cretaceous pollen show an infratectum of only columellate-like elements $(C$. torosus from the Callovian of Siberia, Zavialova 2003; C. torosus from the Barremian of England, Taylor \& Alvin 1984; and C. martinottii from the Albian-Cenomanian? ${ }^{2}$ of Lebanon, Zavialova et al. 2010b). Only C. torosus from England does not fit to this scheme, showing a columellate-like ectexine already in the Rhaetian-Liassic (Pettitt \& Chaloner 1964, pl. I, 1, fig. 1), but I think that additional sections (only one section was shown in the paper) probably would have revealed granules alternating with columellate-like elements.

The third type demonstrates branching columellatelike elements (Fig. 4F); it was found in the Late Cretaceous Classoidites glandis Van Ameron 1965 (Médus 1977, Kedves 1994). Therefore, we can hypothesize rather confidently that the earlier type of the infratectum (one row of large granules) transformed into a columellate-like intratectum in more advanced members; and this infratectum finally evolved in the branching-columellate type in late members of the group.

Classopollis belongs to the morphological group Circumpolles, which included also other pollen types and was rather diverse during the Late Triassic. Apart from Classopollis, no pollen types of this group have ever been found in situ in cheirolepidiaceous cones (as well as in cones of other plant groups). However, in addition to the morphological similarity between Classopollis and other members of Circumpolles, there are some more indirect indices implying that these pollen grains were produced by members of the Cheirolepidiaceae as well. They have been found in the same beds that contain dispersed cheirolepidiaceous cuticles as well as conifer amber and wood. These indices allow one to treat early Circumpolles in the analysis as possible cheirolepidiaceous pollen with a sufficient degree of certainty (Roghi et al. 2006). If we

\footnotetext{
${ }^{1}$ Krassilov et al. (1997) found these pollen grains in guts of a fossil insect from the Mikhailovka (= Aulie) locality of the Karatau Mountain Range in Kazakhstan. Although they mentioned a Late Jurassic age of the enclosing deposits, I state a Callovian with a question mark in the present paper, since Krassilov et al. (1997) repeated the information from Doludenko \& Orlovskaya (1976), who provided paleobotanical and palynological dating. At those times, Soviet paleontologists considered the Callovian as a part of the Upper Jurassic, and while Doludenko \& Orlovskaya (1976) stated that the age is a Late Jurassic, they wrote that the list of pollen and spores they discussed and fossil plants they studied suggested that the age of these lacustrine marls was most probably Callovian.
}

${ }^{2}$ Dr. Dejax (Muséum national d'histoire naturelle, Paris; personal communication; Azar et al. 2011) believes that the palynological assemblage with $C$. martinottii is much older in age than an Albian-Cenomanian. He suspects a Barremian or Aptian age on the basis of photos of the members of the assemblage (Zavialova et al. 2010b) and his knowledge about the stratigraphy of the region, but refrains from any conclusion as far as he did not study the assemblage himself. Therefore, I cite the original dating made in our study by Sophia Smirnova (Zavialova et al. 2010b), but add a question mark. The probable older age of these Lebanon deposits does not influence the proposed reconstruction of the ectexine evolution, though an unequivocal understanding of the age of these deposits is highly desirable.

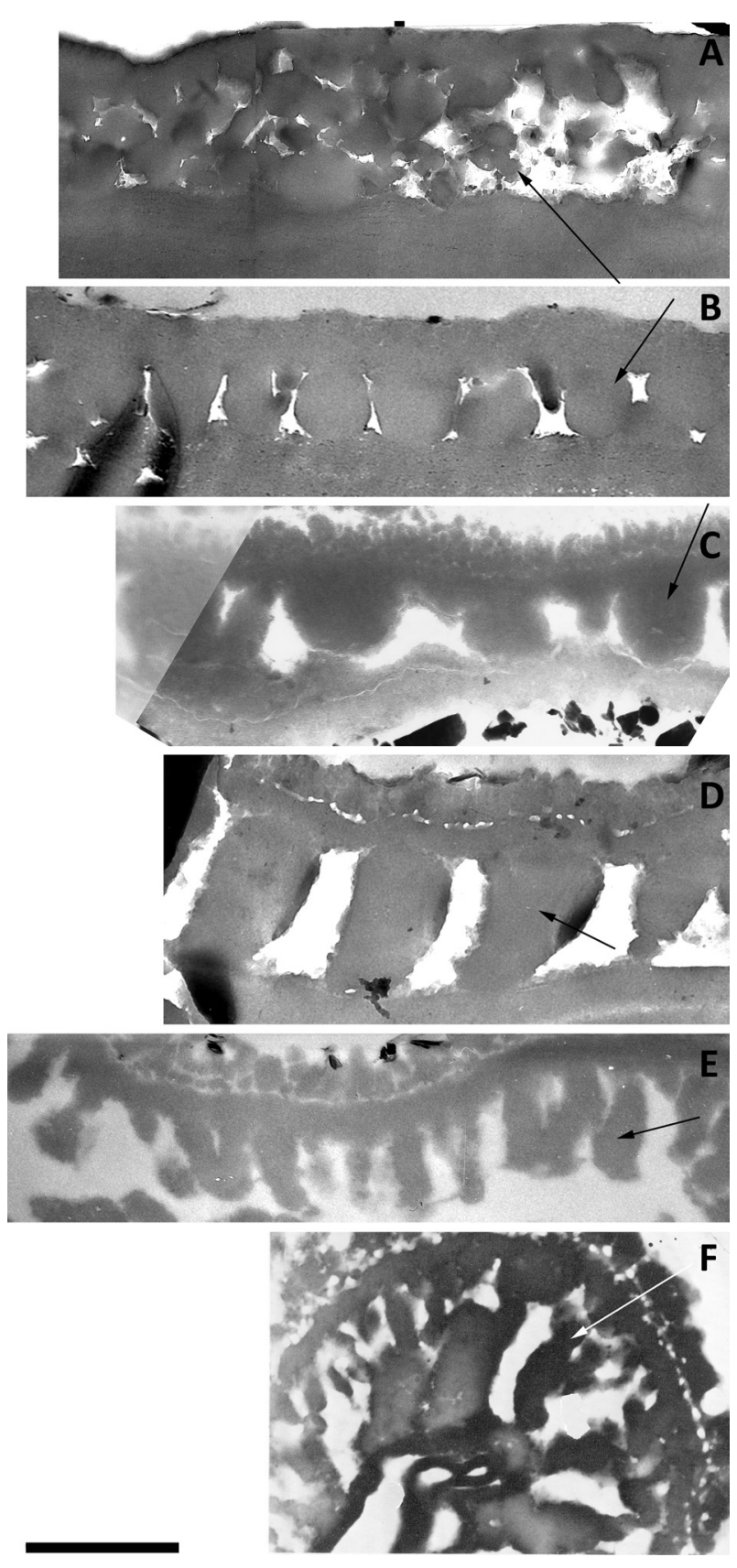

Figure 4 Transformations of the infratectum in members of Circumpolles. Early members of Circumpolles (A: Duplicisporites granulatus, Carnian, Italy) had an infratectum of numerous small irregularly distributed granules. Since the Rhaetian an infratectum appeared that consists of large granules arranged predominantly in one row (B: Classopollis torosus, Rhaetian, England and C: Classopollis meyerana, Callovian?, Kazakhstan). This infratectum gradually transformed during the Jurassic into a columellate-like infratectum (D: Classopollis torosus, Callovian, Siberia and E: Classopollis martinottii, Albian-Cenomanian?, Lebanon). In the Late Cretaceous, the columellate-like infratectum gave rise to an infratectum with branching columellate-like elements (F: Classoidites glandis, Turonian, France). Scale bar $1 \mu \mathrm{m}$. Arrows point on elements of the infratectum. The illustrations are reproduced from Zavialova \& Roghi 2005 (A); Zavialova et al. 2010a (B); Tekleva \& Krassilov 2009 (C); Zavialova 2003 (D); Zavialova et al. 2010b (E); Médus 1977 (F)

assume that early members of Circumpolles were pollen grains of early members of the Cheirolepidiaceae, then the infratectum of one row of large granules can be derived from the infratectum of numerous irregularly distributed small granules (as, for example, in pollen of Duplicisporites granulatus, Fig. 4A; Zavialova \& Roghi 2005). 
This scheme differs from reconstructions, which were earlier proposed for the origin and further morphological evolution of Classopollis. De Jersey (1973) hypothesized a transformation from the Early Triassic Grebespora concentrica Jansonius 1962, through Late Triassic Discisporites psilatus (de Jersey) Reine et al. 1988, to Classopollis meyerana. This idea seems unconvincing both considering the conceivability of the structural transformation and keeping in mind the possible botanical affinity. Indeed, it was later abandoned by its author and Discisporites psilatus was re-interpreted as a lycopsid spore (Reine et al. 1988). Scheuring (1976) proposed a transition from Triadispora to Classopollis, based on data of pollen morphology and keeping in mind the idea that the Cheirolepidiaceae could have originated from the Voltziales (the Majonicaceae) as was supposed by ClementWesterhof \& Van Konijnenburg-van Cittert (1991). The family Majonicaceae is characterized by the Lueckisporites pollen type, which represents, similarly to Triadispora, pollen grains with two protosacci and a small trilete scar. This scheme leaves no place for early Circumpolles. The transition from Triadispora or Lueckisporites to Classopollis also implies a transformation from a protosaccate structure of the ectexine. Such a transformation would lead to an ectexine with, at least occasionally, branching units, which is not the case of Triassic and Jurassic members of Classopollis. The scheme proposed by Schering (1976) is beautiful and agrees with the hypothesis made on macrofossil material. However, it belongs to reconstructions that appear the more convincing the less data are available. Indeed, it would appear better substantiated, if we were aware only about the infratectum with branching units (Fig. 4F).

Classopollis, with its complicated general morphology, apertures of several types, and columellate-like ultrastructure, is a classical example of angiospermization. Possible parallelisms to angiosperm pollen include the transformations of the ectexine ultrastructure, which are similar to transformations that possibly took place in angiosperms. This concerns the development of columellate exine from granular exine. Moreover, the occurrence of branching columellae is known in such advanced angiosperms as the Compositae, similarly to the latest cheirolepidiaceous pollen that also shows branching columellate-like elements of the ectexine. Now it is shown that parallelisms with angiosperms concern not only final stages, but also a chain of similar transformations that could have occurred in these two groups.

In spite of the fact that pollen grains of the Cheirolepidiaceae have been studied with TEM much more often than pollen of most other groups of fossil gymnosperms, further studies are needed. In particular, it would be a long-awaited piece of luck if any pollen grains of early Circumpolles are finally found in pollen organs and become available for a TEM study. Such a study would shed light on the first steps in the evolution of the family. Speaking about late members, the latest material that is so far studied with TEM is dated to the Turonian: branching columellate-like elements were revealed in the ectexine (only one section was published, Médus 1977). Information about post-Turonian members would be very interesting to better substantiate the occurrence of branching elements. It is also not excluded that additional transformations will be detected. Thus, although pollen grains of Classopollis from deposits of different ages show very low variations in dimensions, much larger dispersed pollen grains of Classopollis have been recently found in Danian deposits (Barreda et al. 2012). This discrepancy in dimensions is perhaps an indirect index that the latest members of the genus had differences in their exine ultrastructure as well.

\section{Conclusions}

To conclude, TEM studies of pollen or spores of members of monophyletic groups of higher plants can reveal gradual changes in the morphology and ultrastructure of their pollen or spores. Without TEM data, such changes remain hidden from the scientist and it erroneously seems that a given new morphological type originated suddenly and discretely. It is important to apply this approach to monophyletic groups, then no problems will appear with correct homologization of particular sporoderm layers and structures. The approach is very suitable for groups which existed during a long geological time, and, particularly, which managed to survive until nowadays. They are very promising objects, especially because they allow one to extrapolate on fossil members the information about the sporoderm ontogenesis of their modern descendants.

As such a group, the Cycadales seems a very suitable object, which unfortunately so far lacks enough information for the analysis. The group appeared in the Triassic and has survived until nowadays (Taylor et al. 2009). Currently available data show that the elongated perpendicular alveolae of the ectexine, which are so characteristic of pollen of modern cycads, existed at least as early as in the Jurassic (Zavialova \& Van Konijnenburg-van Cittert, submitted), or, perhaps, even earlier (Klavins et al. 2003). This seems to be the case of evolutionary stability. However, the problem of the aperture is waited for additional information. There is a possibility that some extinct cycads produced inaperturate pollen grains (Tekleva et al. 2007; Zavialova \& Van Konijnenburg-van Cittert 2012), unlike other known fossil cycads and all modern cycads (Audran \& Masure 1977, Meyer 1977, Tekleva et al. 2007). In addition, the aperture of fossil cycads differs from that of modern cycads by the ultrastructure (Zavialova \& Van Konijnenburg-van Cittert, submitted). At the current state of knowledge, what we can discern is a very peculiar diversity in the apertural condition among cycads, but there are not enough data to order this diversity and to reveal any directed changes during the existence of the group.

\section{ACKNOWLEDGEMENTS}

E-mail discussion with Dr. Dejax (Muséum national d'histoire naturelle, Paris) is acknowledged. The study is supported by the Russian Foundation for Basic Research, grant no. 14-04-00044. 


\section{LITERATURE CITED}

Audran, J.C. \& E. Masure 1977. Contribution à la connaissance de la composition des sporodermes chez les Cycadales (Préspermaphytes). Étude en microscopie électronique à transmission (M.E.T.) et à balayage (M.E.B.). Palaeontographica 162:115-158.

Azar, D., J. Dejax \& E. Masure 2011. Palynological analysis of amber-bearing clay from the Lower Cretaceous of central Lebanon. Acta Geological Sinica 85(4):942-249.

Balme, B. 1995. Fossil in situ spores and pollen grains: an annotated catalogue. Review of Palaeobotany and Palynology 87(2-4):81-323.

Barreda, V.D., N.R. Cúneo, P.L. Wilf, E.D. Currano, A. Scasso \& H. Brinkhuis 2012. Cretaceous/Paleogene Floral Turnover in Patagonia: drop in diversity, low extinction and a Classopollis spike. PLoS ONE 7(12): e52455. doi:10.1371/journal.pone.005245.

Chaloner, W.G. 2013. Three palynological puzzles. International Journal of Plant Sciences 174(3):602-607.

Clement-Westerhof, J.A. \& J.H.A. Van Konijnenburg-van Cittert 1991. Hirmeriella muensteri: new data on the fertile organs leading to a revised concept of the Cheirolepidiaceae. Review of Palaeobotany and Palynology 68:147-179.

Doludenko, M.P. \& E.R. Orlovskaya 1976. Jurassic flora of Karatau. Nauka, Moskva, 262 pp. (in Russian). [Аолуденко М.П., Орловская Э.Р. 1976. Юрская флора Каратау. ИзА-во "Наука". Москва. 262 с.].

de Jersey, N.J. 1973. Rimulate pollen grains from the Lower Mesozoic of Queensland. In: Mesozoic and Cainozoic palynology: essays in honour of Isabel Cookson (J.E. Glover \& G. Playford, eds.), pp. 127-140, Special Publication of the Geological Society of Australia, Sydney.

Gomankov, A.V. 1986. Taxonomic affinity of Permian miospores. In: Theory and practice of palynological studies of the Permian and Triassian in the USSR. pp 4-9, Syktyvkar (in Russian) [Гоманьков А.В. 1986. Систематическая принаАлежность пермских миоспор. Теория и практика паминологических исследований перми и триаса СССР. Сыктывкар, с. 4-9. Аеп. ВИНИТИ Ю 4839 В86].

Grauvogel-Stamm, L. \& B. Lugardon 2009. Phylogeny and evolution of horsetails: evidence from spore wall ultrastructure. Review of Palaeobotany and Palynology 156:116-129.

Grauvogel-Stamm, L. \& B. Lugardon 2010. Erratum to: Phylogeny and evolution of horsetails: evidence from spore wall ultrastructure [Rev. Palaeobot. Palynol. 156 (2009): 116-129]. Review of Palaeobotany and Palynology 159: 141-142.

Kedves, M. 1994. Transmission electron microscopy of the fossil gymnosperm exines. Szeged, 125 pp.

Klavins, S.D., E.L. Taylor, M. Krings \& T.N. Taylor 2003. Gymnosperms from the Middle Triassic of Antarctica: the first structurally preserved cycad pollen cone. International Journal of Plant Sciences 164(6):1007-1020.

Krassilov, V.A., V.V. Zherikhin \& A.P. Rasnitsyn 1997. Classopollis in the guts of Jurassic insects. Paleontology 40: 1095-1101.

Lugardon, B. 1985. Observations nouvelles sur l'ultrastructure des Circumpolles. In: IX. Symposium de l'association des palynologues de langue française (A.P.L.F.), Montpellier, Abstract volume, 21.

Lugardon, B. \& C. Brousmuche-Delcambre 1994. Exospore ultrastructure in Carboniferous sphenopsids. In: Ultrastructure of fossil spores andpollen (M.H. Kurmann \& J.A.Doyle, eds.), pp. 53-66, Royal Botanical Garden, Kew.

Médus, J. 1977. The ultrastructure of some Circumpolles. Grana 16:23-29.
Meyer, N.R. 1977. Comparative morphological studies of the development and ultrastructure in the sporoderm of gymnosperms and primitive angiosperms. D. Sci. dissertation. Leningrad, 360 pp., 179 plates (in Russian). [Мейер Н.P. 1977. Сравнительно-морфологические исследования развития и ультраструктуры спородермы голосеменных и покрытосеменных растений. Аиссертация на соиск. ... АОКт. биол. наук. Аенинград. 360 с., 179 фототаблиц].

Orlova, O.A., N.R. Meyer-Melikian \& N.E. Zavialova 2009. A new microsporangiate organ from the Lower Carboniferous of the Novgorod Region, Russia. Paleontological Journal 43(10):1316-1329.

Pettitt, J.M. \& W.G. Chaloner 1964. The ultrastructure of the Mesozoic pollen Classopollis. Pollen et spores 6:611-620.

Petrosianz, M.A. \& N.M. Bondarenko 1983. Characteristic and correlative gymnosperm pollen taxa (Late Cretaceous-Paleogene): pollen of Cheirolepidiaceae: a synopsis. Nauka, Moskva, 79 pp. (in Russian). [Петросьянц М.А., Бондаренко Н.M. 1983. Характерные и коррелятивные таксоны пыльцы голосеменных (поздний мел - палеоген). Пыльца хейролепидиевых. Синопсис. Москва: Наука. 79 с.].

Pocock, S.A.J., G. Vasanthy \& B.S. Venkatachla 1990. Pollen of Circumpolles - an enigma or morphotrends showing evolutionary adaptations. Review of Palaeobotany and Palynology 65:179-193.

Raine, J.I., N.J. de Jersey, \& K.G. Ryan 1988. Ultrastructure and lycopsid affinity of Densoisporites psilatus (de Jersey) comb. nov. from the Triassic of New Zealand and Queensland. Memoirs of the Association of Australasian Palaeontologists 5:79-88.

Roghi G., E. Ragazzi \& P. Gianolla 2006. Triassic amber of the Southern Alps (Italy). Palaios 21:143-154.

Rowley, J.R. \& S.K. Srivastava. 1986. Fine structure of Classopollis exines. Canadian Journal of Botany 64:3059-3074.

Sahashi, N. \& J. Ueno 1986. Pollen morphology of Ginkgo biloba and Cycas revoluta. Canadian Journal of Botany 64: 3075-3078.

Scheuring, B.W. 1976. Proximal exine filaments, a widespread feature among Triassic Protosaccites and Circumpolles to secure the dispersal of entire tetrads. Pollen et spores 18: 611-639.

Taylor, T.N. \& K.L. Alvin 1984. Ultrastructure and development of Mesozoic pollen: Classopollis. American Journal of Botany 71:575-587.

Taylor, T.N. \& E.L. Taylor 1987. The ultrastructure of fossil gymnosperm pollen. Bulletin de la Société botanique de France. 13, Actual. bot. 2:121-140.

Taylor, T.N., E.L. Taylor \& M. Krings 2009. Paleobotany: the biology and evolution of fossil plants. Elsevier, 718 pp.

Tekleva M.V. \& V.A. Krassilov 2009. Modern Gnetales and fossil gnetophytes: comparative pollen morphology and ultrastructure. Review of Palaeobotany and Palynology 156: 130-138.

Tekleva, M.V., S.V. Polevova \& N.E. Zavialova 2007. On some peculiarities of sporoderm ultrastructure in members of the Cycadales and Ginkgoales. Paleontological Journal 41:1162-1178.

Tryon, A.F. \& B. Lugardon 1990. Spores of the Pteridophyta. Surface, wall structure and evolution based on electron microscope studies. Springer Verlag, New York, 648 pp.

Watson, J. 1988. The Cheirolepidiaceae: In: Origin and evolution of gymnosperms (C.B. Beck, ed.), pp. 382-447, Columbia University Press, New York.

Zavialova, N.E. 1998. Morphology and ultrastructure of fossil pollen grains (from the Upper Permian deposits of the Vyakta River and the Lower Jurassic deposits of western 
Siberia). PhD dissertation, Moscow, 280 pp. (in Russian, unpublished). [Завьялова Н.Е. 1998. Морфология и ультраструктура ископаемых пыльцевых зерен (из верхнепермских отложений верховий реки Вятка и нижнеюрских отложений Западной Сибири). Аиссертация на соиск. ... канА. биол. наук. Москва. 280 с.].

Zavialova, N.E. 2003. On the ultrastructure of Classopollis exine: a tetrad from the Jurassic of Siberia. Acta Palaeontologica Sinica 42:1-7.

Zavialova, N., N. Buratti \& G. Roghi 2010a. The ultrastructure of some Rhaetian Circumpolles from southern England. Grana 49:281-299.

Zavialova, N. \& E. Karasev 2015. Exine ultrastructure of in situ Protohaploxypinus from a Permian peltasperm pollen organ, Russian Platform. Review of Palaeobotany and Palynology 213:27-41.

Zavialova, N.E., N.R. Meyer-Melikian \& A.V. Gomankov 2001. Ultrastructure of some Permian pollen grains from the Russian Platform. In: Proceedings of the IX International Palynological Congress, Houston, Texas, U.S.A., 1996 (D.K. Goodman \& R.T. Clarke, eds.), pp. 99-114, American Association of Stratigraphic Palynologists Foundation, New York.
Zavialova, N. \& G. Roghi 2005. Exine morphology and ultrastructure of Duplicisporites from the Triassic of Italy. Grana 44:337-342.

Zavialova, N.E., M.V. Tekleva, S.B. Smirnova \& M. Mroueh 2010. Exine ultrastructure in pollen grains of Classopollis Pflug from the Cretaceous of Lebanon. Paleontological Journal 44(10):1353-1367.

Zavialova, N. \& J.H.A. Van Konijnenburg-van Cittert 2011. Exine ultrastructure of in situ peltasperm pollen from the Rhaetian of Germany and its implications. Review of Palaeobotany and Palynology 168:7-20.

Zavialova, N. \& J.H.A. Van Konijnenburg-van Cittert 2012. Exine ultrastructure of in situ pollen from the cycadalean cone Androstrobus prisma Thomas et Harris 1960 from the Jurassic of England. Review of Palaeobotany and Palynology 173:15-22.

Zavialova, N. \& J.H.A. Van Konijnenburg-van Cittert. Exine ultrastructure of in situ pollen from the cycadalean cone Androstrobus manis Harris 1941 from the Jurassic of England. Review of Palaeobotany and Palynology (submitted). 